\title{
Modeling and measuring intracellular fluxes of secreted recombinant protein in Pichia pastoris with a novel ${ }^{34} \mathrm{~S}$ labeling procedure
}

\author{
Martin Pfeffer ${ }^{1}$, Michael Maurer ${ }^{1,2^{*}}$, Gunda Köllensperger ${ }^{3,4}$, Stephan Hann ${ }^{3,4}$, Alexandra B Graf ${ }^{2}$ and \\ Diethard Mattanovich ${ }^{1,4}$
}

\begin{abstract}
Background: The budding yeast Pichia pastoris is widely used for protein production. To determine the best suitable strategy for strain improvement, especially for high secretion, quantitative data of intracellular fluxes of recombinant protein are very important. Especially the balance between intracellular protein formation, degradation and secretion defines the major bottleneck of the production system. Because these parameters are different for unlimited growth (shake flask) and carbon-limited growth (bioreactor) conditions, they should be determined under "production like" conditions. Thus labeling procedures must be compatible with minimal production media and the usage of bioreactors. The inorganic and non-radioactive ${ }^{34} \mathrm{~S}$ labeled sodium sulfate meets both demands.

Results: We used a novel labeling method with the stable sulfur isotope ${ }^{34} \mathrm{~S}$, administered as sodium sulfate, which is performed during chemostat culivations. The intra- and extracellular sulfur 32 to 34 ratios of purified recombinant protein, the antibody fragment Fab3H6, are measured by HPLC-ICP-MS. The kinetic model described here is necessary to calculate the kinetic parameters from sulfur ratios of consecutive samples as well as for sensitivity analysis. From the total amount of protein produced intracellularly $\left(143.1 \mathrm{\mu g} \mathrm{g}^{-1} \mathrm{~h}^{-1}\right.$ protein per yeast dry mass and time) about 58\% are degraded within the cell, 35\% are secreted to the exterior and $7 \%$ are inherited to the daughter cells.

Conclusions: A novel ${ }^{34} \mathrm{~S}$ labeling procedure that enables in vivo quantification of intracellular fluxes of recombinant protein under "production like" conditions is described. Subsequent sensitivity analysis of the fluxes by using MATLAB, indicate the most promising approaches for strain improvement towards increased secretion.
\end{abstract}

\section{Background}

The production of recombinant proteins in yeast has to compete with other host organisms, mainly bacteria and mammalian cell lines. Strain improvement therefore is an essential step between the discovery of a new protein and its large scale production. Yeasts like Pichia pastoris grow faster and to a higher cell density compared to mammalian cells, however the low specific productivity (the amount of secreted protein per unit biomass and time) is their major drawback [1]. A lot of efforts have already been made to find and overcome specific

\footnotetext{
* Correspondence: michael.maurer@fh-campuswien.ac.at

'University of Natural Resources and Life Sciences, Department of

Biotechnology, Muthgasse 18, 1190 Vienna, Austria

Full list of author information is available at the end of the article
}

bottlenecks in the cellular protein production and secretory system [reviewed by [2]].

At genomic level increasing the gene copy number as well as the promoter strength leads to higher productivities [3-5]. The overload of the endoplasmic reticulum (ER) with recombinant protein may induce the unfolded protein response (UPR) [6-8] followed by enhanced ERassociated degradation (ERAD) $[9,10]$. Among many other things, UPR reduces overall translation speed [11] and enforces ERAD via the Ire1 signaling cascade [12]. ERAD causes proteolytic digestion of malfolded protein in the cytosolic proteasome [13]. Thus, reduced ERstress can be beneficial for recombinant protein production. Therefore, many attempts have been made to improve the complex process of protein maturation,

\section{Biomed Central}


mainly by co-overexpressing ER resident chaperons or foldases like BiP / Kar2, Pdi1 or calnexin [14-16]. Furthermore the transport from the ER to the Golgi and finally into the exterior can be improved by co-overexpression of proteins involved in this pathways. Examples are Sso1 and Sso2, both coding for plasma membrane tSNARE proteins [17] or Cog6, Coy1 and Bmh2, all coding for proteins involved in vesicular transport [18].

In the strain improvement process by cell engineering it is required to achieve high yields in short time. A focused and systematic approach therefore would be to identify the most important bottleneck in recombinant protein synthesis being the one which modification has the highest impact on protein titers.

Kinetic models are a valuable tool in this regard, as they give insights into intracellular fluxes. The formal kinetic description of the processing and transport of secreted proteins are already known for quite a while $[19,20]$. However, the challenge is the experimental determination of the parameters needed in those models. Furthermore it is necessary to make as few assumptions as possible so that a production process can still be described. In this regard the experiments have to be done under carbon limited, production "similar", growth in bioreactors under defined and controlled conditions instead of using shake flask cultivations. This is usually not possible when labeling is performed with radioactive isotopes or when protein kinetics is measured with microscopic tools, like fluorescence microscope imaging. Handling of large volumes of radioactive material is not feasible for risk of contamination. Microscopic imaging on the other side quantifies the protein fluxes by comparing images of living cells over time [21]. The advantage is that single cells are analyzed instead of an average. However cells are exposed to non-defined conditions which are likely to be different to the bioreactor. Furthermore, this method is limited to fluorescent or fluorescent-tagged proteins.

It is important that the model of choice accounts for intracellular degradation as well, because a substantial amount of recombinant protein may be degraded via ERAD or other pathways. Also the dilution by growth, especially in the fast growing prokaryotes and yeast cells, has to be taken into account. For example at a specific growth rate $\mu=0.1 \mathrm{~h}^{-1}, 7 \%$ of the intracellular protein is inherited to the daughter cells (as described in this study). Several kinetic model studies for antibody production have been developed [22-25], but intracellular protein degradation as well as protein inheritance to the daughter cells was not taken into account in these cases.

In this work we present a novel ${ }^{34} \mathrm{~S}$ labeling method during chemostat cultivation, providing data to consider intracellular protein formation, intracellular degradation, secretion and dilution by growth in the kinetic model.
Further sensitivity analysis of the intracellular protein flux enables the estimation of their impact and serves as a decisions basis for further strain improvement.

\section{Results}

\section{Structured Kinetic Model}

The structured kinetic model describes the intra- and extracellular recombinant protein pools. The dynamics of the intra- and extracellular Fab3H6 pools are expressed in two separate differential equations (1) and (3), which are modified from Noe and Delenick [19] and Batt and Kompala [20].

The amount of intracellular protein $(\mathrm{Pi})$ depends on the fluxes of intracellular protein formation $\left(\mathrm{q}_{\mathrm{Pi}_{\mathrm{i}}}\right)$, protein secretion $\left(\mathrm{q}_{\mathrm{Sec}}\right)$, intracellular protein degradation $\left(\mathrm{q}_{\mathrm{Deg}}\right)$ and protein dilution into the daughter cells $\left(\mathrm{q}_{\mathrm{Dii}}\right)$. Due to the rapid growth of yeast cells, the inheritance of protein to daughter cells has to be taken into account. The dynamics of protein secretion, degradation and dilution can be assumed to be a first-order kinetic $[22,23,26]$, with specific time constants (K). Equation (1) can therefore be transformed into equation (2).

$$
\begin{aligned}
& \frac{\mathrm{d}[\mathrm{P}]}{\mathrm{dt}}=\mathrm{q}_{\mathrm{Pi}}-\mathrm{q}_{\mathrm{SeC}}-\mathrm{q}_{\text {Deg }}-\mathrm{q}_{\text {Dil }} \\
& \frac{\mathrm{d}[\mathrm{P}]_{\mathrm{i}}}{\mathrm{dt}}=\mathrm{q}_{\mathrm{Pi}}-\mathrm{K}_{\mathrm{Sec}} \bullet[\mathrm{P}]_{\mathrm{i}}-\mathrm{K}_{\text {Deg }} \bullet[\mathrm{P}]_{\mathrm{i}}-\mathrm{K}_{\text {Dil }} \bullet[\mathrm{P}]_{\mathrm{i}}
\end{aligned}
$$

In chemostat culture, the extracellular product pool $(\mathrm{Pe})$ is a function of the secreted protein $\left(\mathrm{q}_{\mathrm{Sec}}\right)$ and the amount of protein in the media that is harvested $\left(\mathrm{q}_{\mathrm{Har}}\right)$ (equation 3). Also here first-order kinetic can be assumed and equation (3) transformed into equation (4).

$$
\begin{aligned}
& \frac{\mathrm{d}[\mathrm{P}]_{e}}{\mathrm{dt}}=\mathrm{q}_{\mathrm{Sec}}-\mathrm{q}_{\mathrm{Har}} \\
& \frac{\mathrm{d}[\mathrm{P}]_{\mathrm{e}}}{\mathrm{dt}}=\mathrm{K}_{\mathrm{Sec}} \bullet[\mathrm{P}]_{\mathrm{i}}-\mathrm{K}_{\mathrm{Har}} \bullet[\mathrm{P}]_{\mathrm{e}}=\mathrm{K}_{\mathrm{Sec}} \bullet[\mathrm{P}]_{\mathrm{i}}-\mathrm{K}_{\mathrm{Dil}} \bullet[\mathrm{P}]_{e}
\end{aligned}
$$

The observed viability of more than $99.0 \%$ ensures that the dilution rate (D) and the specific growth rate $(\mu)$ are equal in these continuous cultivations and thus also the time constants of dilution $\mathrm{K}_{\mathrm{Dil}}$ and harvest $\mathrm{K}_{\mathrm{Har}}$ are the same.

\section{Calculation of the time constants for secretion $\mathrm{K}_{\mathrm{Sec}}$ and degradation $\mathrm{K}_{\mathrm{Deg}}$}

Due to steady state conditions during continuous cultivation no change in the total amount of $\mathrm{P}_{\mathrm{i}}$ or $\mathrm{P}_{\mathrm{e}}$ occurred over time. Therefore equation (4) is zero and can be transformed into equation (5).

$$
\mathrm{K}_{\mathrm{Sec}}=\mathrm{K}_{\mathrm{Dil}} \bullet \frac{[\mathrm{P}]_{\mathrm{e}}}{[\mathrm{P}]_{\mathrm{i}}}
$$


To determine the time constant for protein degradation $\mathrm{K}_{\text {Deg, }}$, the decrease of the amount of ${ }^{32} \mathrm{~S}$-containing protein $\left(\mathrm{P}^{32} \mathrm{~S}\right)$ during the continuous labeling experiment with ${ }^{34} \mathrm{~S}$ is used. The fraction of non-labeled sodium sulfate during labeling remains always below $1 \%$. It is therefore assumed that the intracellular ${ }^{32} \mathrm{~S}$ protein formation during labeling is negligible. Thus equation (2) can be converted to equation (6) and further simplified for $\mathrm{q}_{(\mathrm{Pi} 32 \mathrm{~S})}$ (equation 7). The solution of this new differential equation can be transformed into a linear system, shown in equation (8).

$$
\begin{aligned}
& \frac{\mathrm{d}\left[\mathrm{P}^{32} \mathrm{~S}_{i}\right.}{\mathrm{dt}}=\mathrm{qP}_{i}^{32} \mathrm{~S}-\mathrm{K}_{\mathrm{Sec}} \bullet\left[\mathrm{P}^{32} \mathrm{~S}\right]_{i}-\mathrm{K}_{\mathrm{Deg}} \bullet\left[\mathrm{P}^{32} \mathrm{~S}\right]_{\mathrm{i}}-\mathrm{K}_{\mathrm{Dil}} \bullet\left[\mathrm{P}^{32} \mathrm{~S}\right]_{\mathrm{i}} \\
& \frac{\mathrm{d}\left[\mathrm{P}^{32} \mathrm{~S}\right]_{i}}{\mathrm{dt}}=-\left[\mathrm{P}^{32} \mathrm{~S}\right]_{\mathrm{i}} \bullet\left(\mathrm{K}_{\mathrm{Sec}}+\mathrm{K}_{\mathrm{Deg}}+\mathrm{K}_{\mathrm{Dil}}\right) \\
& \ln \frac{\left[\mathrm{P}^{32} \mathrm{~S}\right]_{\mathrm{i}}(\mathrm{t})}{\left[\mathrm{P}^{32} \mathrm{~S}\right]_{\mathrm{i}}(\mathrm{t}=0)}=-\left(\mathrm{K}_{\mathrm{Deg}}+\mathrm{K}_{\mathrm{Sec}}+\mathrm{K}_{\mathrm{Dil}}\right) \bullet \mathrm{t}
\end{aligned}
$$

Linear regression analysis was performed with the statistics software package R. The slope represents the sum of the three time constants for degradation, secretion and dilution. $K_{\text {Deg }}$ is calculated by subtracting the known $\mathrm{K}_{\mathrm{Sec}}$ and $\mathrm{K}_{\mathrm{Dil}}$ from the absolute value of the slope.

\section{Calculation of the rate of intracellular recombinant protein formation $\left(\mathrm{q}_{\mathrm{P}_{\mathrm{i}}}\right)$}

Due to steady state considerations, equation (1) can be set to zero. The result is shown in equation (9), were $q_{p i}$ is depicted. This equation expresses that all protein that is secreted, degraded or transferred into daughter cells is produced in the cells before.

$$
\mathrm{q}_{\mathrm{Pi}}=[\mathrm{P}]_{\mathrm{i}} \bullet\left(\mathrm{K}_{\mathrm{SeC}}+\mathrm{K}_{\mathrm{Deg}}+\mathrm{K}_{\mathrm{Dil}}\right)
$$

\section{Chemostat cultivation}

Extracellular and intracellular Fab3H6 concentrations remained constant over time (data not shown). The average concentrations were $91.8 \mu \mathrm{g}$ per gram YDM (STD: 9.6\%) intracellular and $507.5 \mu \mathrm{g}$ per gram YDM extracellular (STD: 12.1\%). The standard deviation (STD) derived from two independent chemostat cultivations.

\section{Immunoprecipitation}

The antibody fragment Fab3H6 was immunopurified during the continuous labeling from the fermentation supernatants and the cell biomass respectively (figure 1). In the supernatant almost only the dimer was present, whereas the cell lysate contained a substantial amount of monomers. Some impurities were detected in the

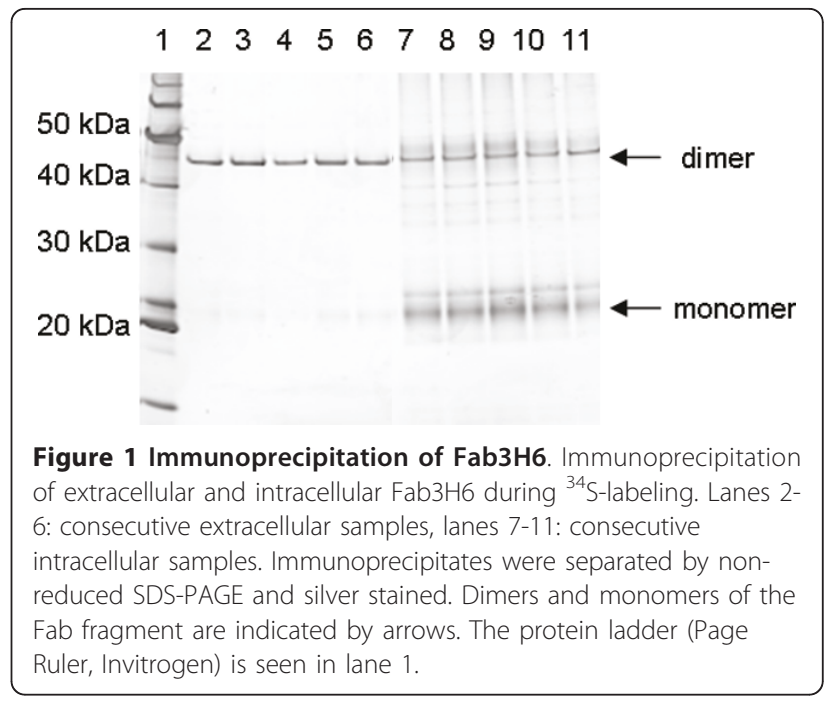

immunoprecipitates (IPs) from the cell lysates. This might be a result of covalent and hydrophobic interactions of the nascent peptide chains during folding, assembly and transport. Therefore the decrease of the intracellular ${ }^{32} \mathrm{~S} /{ }^{34} \mathrm{~S}$ ratio has to be corrected by subtracting the background levels derived from impurities. According to the observed half times of secretion and degradation (table 1), all intracellular recombinant protein should contain less than $0.1 \%{ }^{32} \mathrm{~S} 140$ min post labeling. Therefore it is assumed that from this time point on the measured ${ }^{32} \mathrm{~S}$ signal derived from impurities. The background was calculated by extrapolating the ${ }^{32} \mathrm{~S} /{ }^{34} \mathrm{~S}$ ratios from 140 min post labeling on towards the beginning of the labeling.

\section{Sulfur isotopic distribution during labeling}

The ${ }^{32} \mathrm{~S}$ amount of compounds smaller than $3 \mathrm{kDa}$, mainly sulfate, in the media is shown in figure $2 \mathrm{~A}$ (open circles). The values are always around or below $1 \%$, which is a prerequisite for the kinetic model (equation 7). The decrease of the unlabeled antibody fragment Fab3H6 from two replicative, independent chemostat cultivations is shown in figure $2 \mathrm{~A}$ and $2 \mathrm{~B}$. The amount of intracellular non-labeled ${ }^{32} \mathrm{~S}$ recombinant protein is always below the extracellular value. This is not surprising because labeled protein has to be produced within the cell before being released to the media. In some samples the signal to noise ratio was not sufficient for ICP-MS measurement so that these were not taken into account. Therefore, the number of data points in figure $2 \mathrm{~A}$ and figure $2 \mathrm{~B}$ are not identical.

\section{Intracellular Fab3H6 fluxes}

The dilution rate of the chemostat defines the growth rate of the culture. The specific growth rate expressed 
Table 1 Intracellular fluxes of the antibody fragment Fab3H6

\begin{tabular}{|c|c|c|c|}
\hline flux & rate $(q)$ & time constant $(K)$ & half time $\left(t_{1 / 2}\right)$ \\
\hline $\begin{array}{l}\text { intracellular protein } \\
\text { formation (Pi) }\end{array}$ & $143.1 \mathrm{\mu g} \mathrm{g}^{-1} \mathrm{~h}^{-1}$ (STD 8.8\%) & & \\
\hline $\begin{array}{l}\text { intracellular protein } \\
\text { degradation (Deg) }\end{array}$ & $83.3 \mu \mathrm{g} \mathrm{g}^{-1} \mathrm{~h}^{-1}$ (STD 9.3\%) & $0.0151 \mathrm{~min}^{-1}$ (STD 2.8\%) & $45.8 \min$ (STD 2.8\%) \\
\hline protein secretion (Sec) & $50.7 \mu \mathrm{g} \mathrm{g}^{-1} \mathrm{~h}^{-1}$ (STD 12.1\%) & $0.00920 \mathrm{~min}^{-1}$ (STD 2.5\%) & $75.3 \min ($ STD 2.5\%) \\
\hline dilution by growth (Dil) & $9.18 \mu \mathrm{g} \mathrm{g}^{-1} \mathrm{~h}^{-1}$ (STD 9.6\%) & $0.00167 \mathrm{~min}^{-1}$ (STD 0.05\%) & $415.9 \min ($ STD 0.05\%) \\
\hline
\end{tabular}

The intracellular fluxes are represented as rates $\mathrm{q}\left(\mu \mathrm{g}\right.$ Fab3H6 $\left.(\mathrm{g} \mathrm{YDM})^{-1} \mathrm{~h}^{-1}\right)$, time constants $\mathrm{K}\left(\mathrm{min}^{-1}\right)$ or half times $(\mathrm{min})$. STD $=\mathrm{standard} \mathrm{deviation;} \mathrm{n}=2$ independent replicate chemostat cultivations.

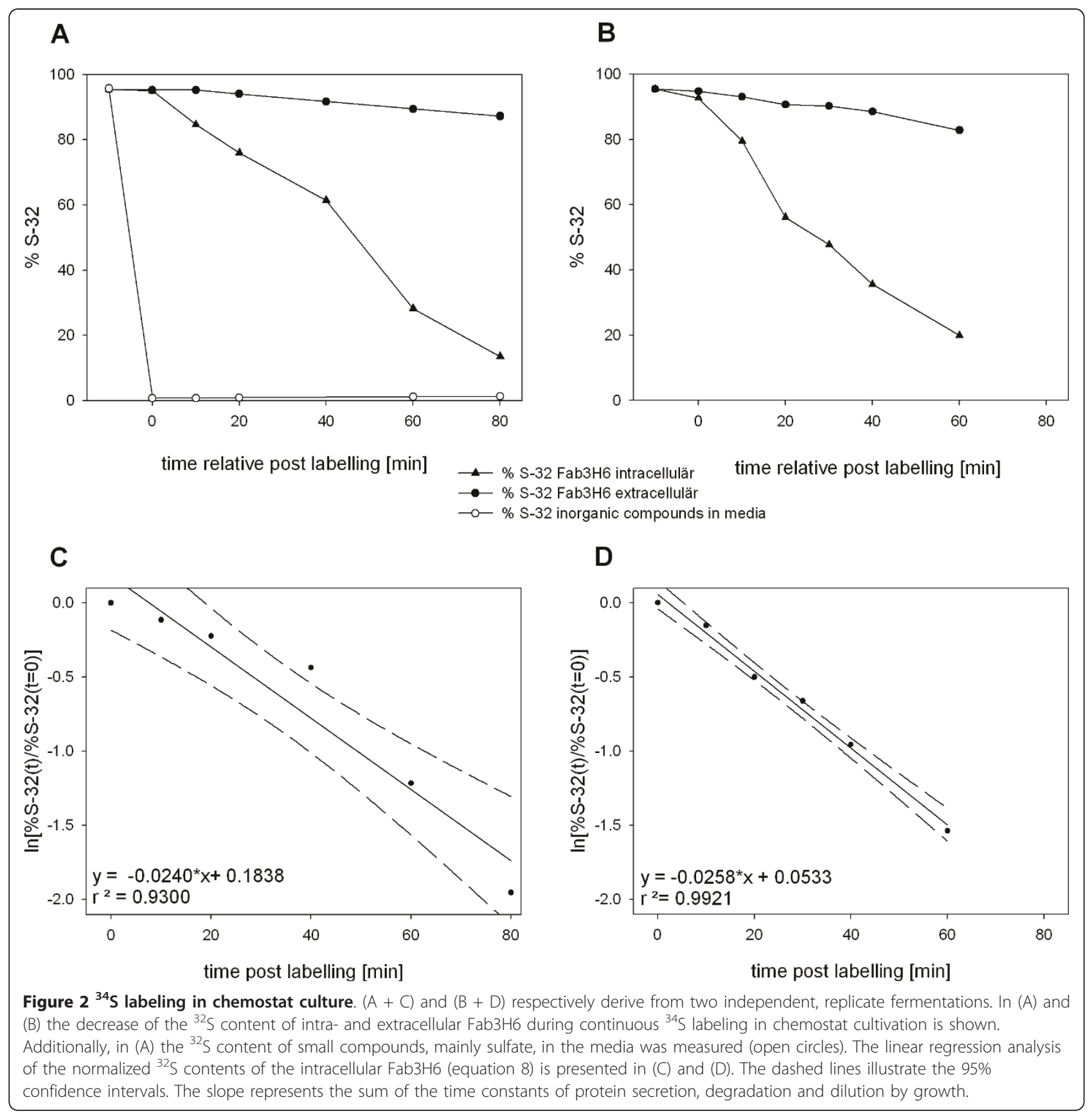


in minutes equates the time constant of the dilution by growth $\mathrm{K}_{\text {Dil }}=0.00167 \mathrm{~min}^{-1}$ (table 1). The corresponding half time $\mathrm{t}_{1 / 2}$ Dil $=415.9 \mathrm{~min}$ is calculated by equation (10):

$$
\mathrm{t}_{1 / 2 \text { Dil }}=\frac{\ln (2)}{K_{\text {Dil }}}
$$

The relative standard deviation (STD) of $0.05 \%$ results from the discontinuous harvest (see material an methods). The rate by which the protein is inherited to the daughter cells $\mathrm{q}_{\text {Dil }}=9.18 \mu \mathrm{g} \mathrm{g}^{-1} \mathrm{~h}^{-1}$ (STD: 9.6\%).

For the determination of $\mathrm{K}_{\mathrm{Sec}}$ the quotient from extraand intracellular protein concentration is multiplied with $\mathrm{K}_{\text {Dil }}$ (equation 5). $\mathrm{K}_{\mathrm{Sec}}$ was calculated to be $0.0092 \mathrm{~min}^{-1}$ (STD: $2.5 \%$ ) with the corresponding half time $\mathrm{t}_{1 / 2 \mathrm{Sec}}=$ 75.3 minutes (STD: $2.5 \%$ ) and the secretion rate $\mathrm{q}_{\mathrm{Sec}}=$ $50.7 \mu \mathrm{g} \mathrm{g}^{-1} \mathrm{~h}^{-1}$ (STD: 12.1\%) (table 1).

Before the degradation rate can be calculated, the intracellular values of the unlabeled ${ }^{32} \mathrm{~S}$ Fab3H6 content (see figure 2B) have to be transformed according to equation (8). This is done by taking the logarithm of the normalized data points. The linear regression analyses of the two biological replicates are shown in figure $2 \mathrm{C}$ and figure $2 \mathrm{D}$ respectively, with the transformed values on the $\mathrm{y}$-axis and the time on the $\mathrm{x}$-axis. $\mathrm{K}_{\mathrm{Deg}}$ is calculated by subtracting $\mathrm{K}_{\mathrm{Sec}}$ and $\mathrm{K}_{\mathrm{Dil}}$ from the positive slopes $0.0240 \mathrm{~min}^{-1}$ and $0.0258 \mathrm{~min}^{-1}$. The time constant for intracellular degradation $\mathrm{K}_{\mathrm{Deg}}=0.0151 \mathrm{~min}^{-1}$ (STD 2.8\%) with the corresponding $\mathrm{t}_{1 / 2}$ Deg $=45.8 \mathrm{~min}$ (STD 2.8\%) and $\mathrm{q}_{\mathrm{Deg}}=83.3 \mu \mathrm{g} \mathrm{g}^{-1} \mathrm{~h}^{-1}$ (STD: 9.3\%). Furthermore, the $95 \%$ confidence interval is represented by the dashed line in figure $2 \mathrm{D}$.

The rate of intracellular protein formation $\mathrm{q}_{\mathrm{Pi}}$ is simply the sum of $\mathrm{q}_{\mathrm{Dil}}, \mathrm{q}_{\mathrm{Sec}}$ and $\mathrm{q}_{\mathrm{Deg}}$ and is $143.1 \mu \mathrm{g} \mathrm{g}^{-1} \mathrm{~h}^{-1}$ (STD: 8.8\%).

Figure 3 gives an overview of the rates, where $\mathrm{q}_{\mathrm{Pi}}$ of $143.1 \mu \mathrm{g} \mathrm{g}^{-1} \mathrm{~h}^{-1}$ represent $100 \%$. The other rates ( $\mathrm{q}_{\mathrm{Deg}}$, $\mathrm{q}_{\mathrm{Sec}}$ and $\left.\mathrm{q}_{\mathrm{Dil}}\right)$ are shown relative to the intracellular protein formation. From $100 \%$ being produced within the cell, $58 \%$ are degraded intracellularly, $35 \%$ are secreted to the exterior and $7 \%$ are inherited to daughter cells.

\section{Sensitivity analysis}

The sensitivity analysis reflecting the impact of the different model parameters to the extracellular Fab3H6 concentration is shown in figure 4. Parameters, describing either protein formation $\left(\mathrm{q}_{\mathrm{Pi}}\right)$, secretion $\left(\mathrm{t}_{1 / 2} \mathrm{Sec}\right)$ or degradation $\left(t_{1 / 2}\right.$ Deg $)$ are continuously changed in MATLAB from their starting point up to $+/-10$ fold. Each fold increase or decrease is pictured as a solid line. In the three dimensional plots, two of the model parameters are plotted against the corresponding Fab3H6 titers, resulting in the presented areas (figure 4A-D).

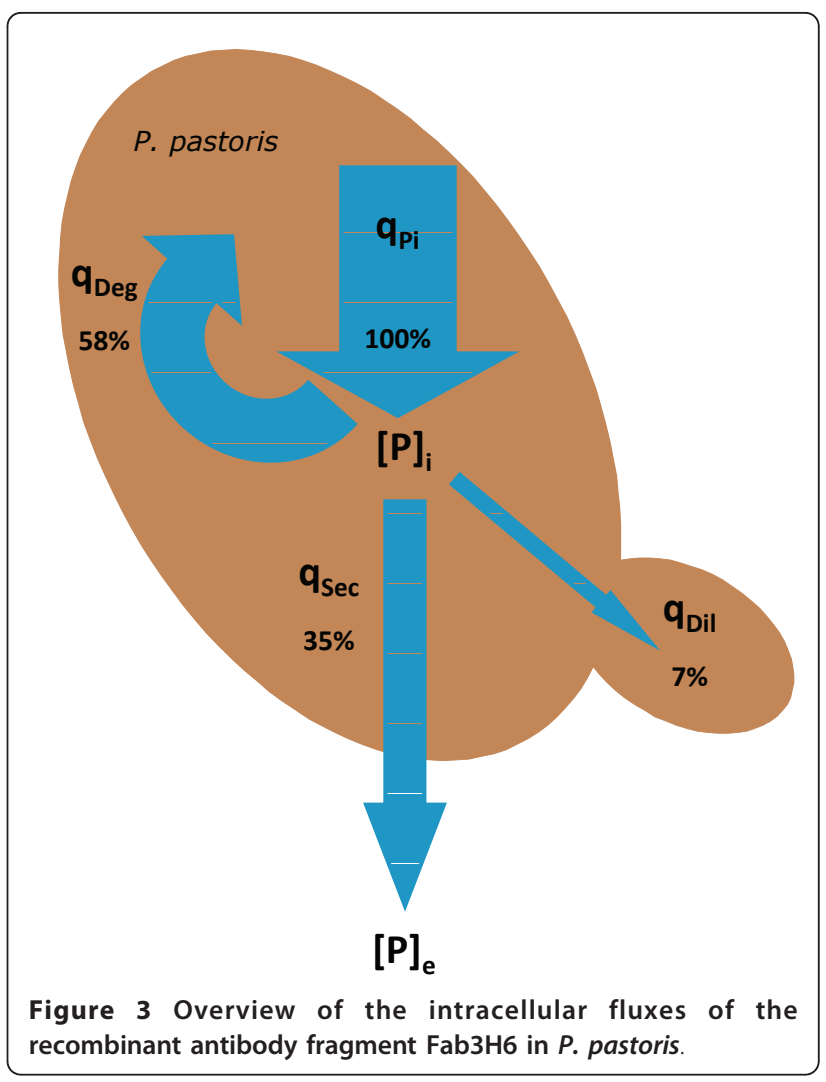

The 10 fold improvement of each parameter is shown as a white arrow.

A 10 fold "faster" secretion, $\mathrm{t}_{1 / 2 \mathrm{Sec}}=7.5 \mathrm{~min}$, would increase extracellular Fab3H6 concentration by the factor 2.5. A 10 fold "improved" degradation, $\mathrm{t}_{1 / 2}$ Deg $=458$ min, results in a 2.0 fold increase. By combining both effects the titers are estimated to be 3.5 fold higher (figure $4 \mathrm{~A}$ ).

The intracellular protein formation rate $\mathrm{q}_{\mathrm{pi}}$ has an almost linear effect on the extracellular protein concentration (figure $4 \mathrm{~B}$ and figure $4 \mathrm{C}$ ). By increasing $\mathrm{q}_{\mathrm{Pi}}$ by the factor of 10 , from $143.1 \mu \mathrm{g} \mathrm{g}^{-1} \mathrm{~h}^{-1}$ to $1.43 \mathrm{mg} \mathrm{g}^{-1} \mathrm{~h}^{-}$ ${ }^{1}$, the predicted Fab3H6 concentrations are also enhanced by approximately the same factor to about $5000 \mu \mathrm{g} \mathrm{g}{ }^{-1}$.

In figure $4 \mathrm{~A}-\mathrm{C}$ no limit in the secretion pathway was anticipated in the underling kinetic model. This assumption however is not realistic, especially in yeast cells. It has been reported many times that the secretory capacity can be a bottleneck during recombinant protein production $[2,4,14,18]$. Therefore, an additional model constraint was implemented in figure $4 \mathrm{D}$, where the maximum secretion rate was set to be twice the default value. As a result the Fab3H6 titers reach a plateau that can be achieved by improving either $t_{1 / 2}$ Deg or $\mathrm{q}_{\mathrm{P} i}$. However the efforts by which the two parameters have to be varied are different, the degradation has to be 

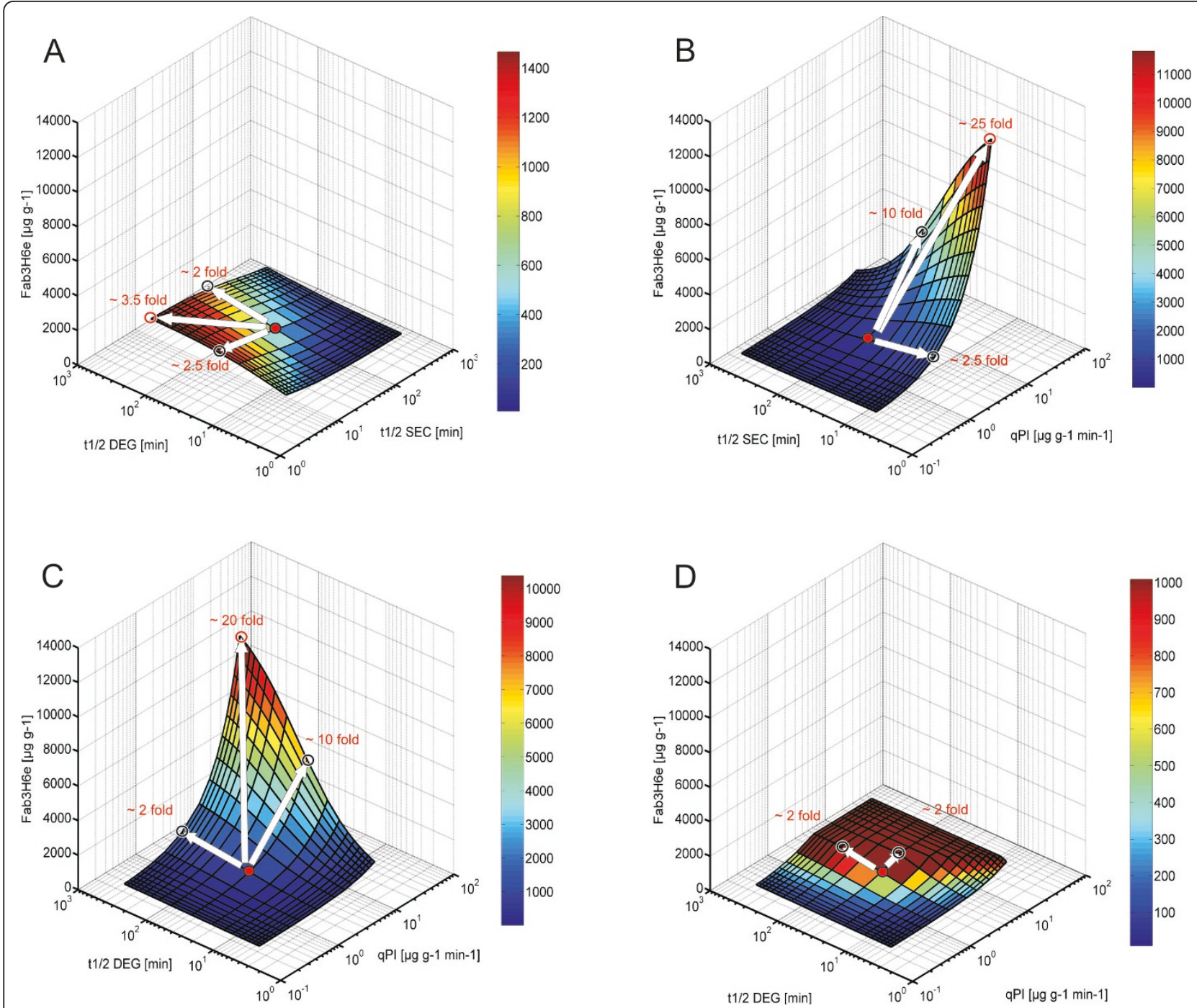

Figure 4 Sensitivity analysis of the extracellular Fab3H6 concentration. In each picture the effect of two different input variables on the extracellular Fab3H6 concentration is shown. The red dot in the middle represents the measured values in the chemostat. These initial values were changed from -10 to +10 fold resulting in depicted areas. In (A) $t_{1 / 2}$ Deg and $t_{1 / 2}$ Sec in (B) $t_{1 / 2}$ Sec and $q_{p i}$, in (C) and (D) $t_{1 / 2}$ Deg and $q_{P i}$ were analyzed. Furthermore, in (D) the maximum secretion capacity was set to $101.4 \mathrm{\mu g} \mathrm{g}^{-1} \mathrm{~h}^{-1}$ (2 fold of the measured value).

changed by the factor of 4-6 and the intracellular protein formation by the factor 2 .

\section{Discussion}

Kinetic models describing the cellular fluxes of recombinant secreted proteins are available as well as their mathematic solutions $[19,20]$. However, in their practical application these models have usually been simplified by omission of parameters like dilution by growth as well as intracellular degradation. In our experiments we showed that $\mathrm{q}_{\mathrm{Deg}}$ and $\mathrm{q}_{\mathrm{Dil}}$ are of substantial dimensions, together being $65 \%$ of all intracellular synthesized protein. Therefore, especially if a model should be applied for further strain improvement applications, it appears to be essential that those parameters are considered in the model at least in microbial expression systems.

Growth conditions like specific growth rate, media composition or oxygen limitations, just to name some, affect recombinant protein production and thus alter its intracellular flux $[27,28]$ So, it is necessary that the fluxes are measured under defined and reproducible conditions. In our case this is done in carbon limited chemostat cultivations using chemically defined minimal medium. Labeling with the non-radioactive and inorganic sulfur-isotope ${ }^{34} \mathrm{~S}$, administered as sodium sulfate, enables the usage of bioreactors and a standard minimal production medium without amino acids. The common 
protein labeling procedures with radioactively labeled amino acids like ${ }^{35} \mathrm{~S}$ and ${ }^{3} \mathrm{H}$ do not meet these demands.

Continuous labeling does not require any washing and centrifugation steps of the biomass and thus avoids the physiologically undefined conditions during this procedure. Non-labeled ${ }^{32} \mathrm{~S}$ and labeled ${ }^{34} \mathrm{~S}$ are measured simultaneously and thus the continuous labeling can be also interpreted as a chase of ${ }^{32} \mathrm{~S}$. Therefore the same amount of information like with a pulse-chase experiment using common ${ }^{35} \mathrm{~S}$ amino acid labeling can be obtained. However, the detection limits, mainly depending on the resolution of the mass spectrometry, might be higher.

For efficient labeling, all sources of sulfur "contaminations" have to be avoided. This means that the sulfur in the media, and the trace salt solution within, has to be reduced to only one source, the labeled sodium sulfate. In our case the necessary changes were minimal, just the anions of the salts had to be adapted. The remaining sulfate concentration in the culture broth was quantified by nephelometric analysis with $\mathrm{BaCl}_{2}$. It contained about $10 \%$ of the sulfate of the feed medium. The amount of pulsed sodium sulfate has to be chosen due to labeling and osmolaric considerations. The nonlabeled sulfate should be low and the change in osmolarity should not affect the protein fluxes. With the addition of $600 \mathrm{mg}$ labeled sodium sulfate, the ${ }^{32} \mathrm{~S}$ concentration was below 1\% throughout the experiment and the osmolarity increase was not detectable.

With this experimental setup the time constants and the corresponding half times of intracellular formation, intracellular degradation, dilution by growth as well as for secretion of the product can be determined. In the case of the recombinant secreted Fab3H6 35\% of the protein is secreted wereas the majority (58\%) is intracellularly degraded. The half time of protein degradation is 45.8 minutes, which is similar to the average half time of $S$. cerevisiae proteins, being 43 minutes [26]. The half time of secretion of 75.3 minutes seems to be rather slow, compared to e.g. carboxypeptidase in yeast [29]. However, the antibody fragment Fab3H6 is a heterodimer and thus could be more difficult to assembly and to secrete. In NS0 cells, Yee et al. [30] reported a half-time of one hour for IgG secretion for the major fraction of (70\%) of IgG molecules. The remaining amount had a half-time close to the doubling time of NSO.

The major application of the model should be the support of a systematic strain improvement process. Therefore three dimensional sensitivity analyses were performed (figure 4). The impact of each parameter on overall expression titers as well as their synergistic effect was estimated. A ten fold improvement of the degradation or secretion half time resulted in two to three fold increased protein titers, respectively. Similar fold changes are often achieved when protein folding is engineered, like via PDI1 or BiP / KAR2 over-expression $[14,15]$. The protein synthesis rate, however, affects the secreted protein titer in a linear manner. By increasing the gene copy numbers, ten fold or higher protein production rates have already been achieved [3,31]. The linear correlation between gene copy numbers and expression levels may only be valid as long as no bottlenecks in folding or secretion occur [4]. Figure 4D takes a limitation in the secretory pathway into account. As a result protein titers reach a plateau, where further increase in the protein formation rate has no more effect. In such situations cell engineering of the secretory pathway may be the only way to break through the plateau by opening the secretion bottleneck.

Sensitivity analysis gives hints which parameter is most worthy to be modified in this regard. However strain development is an iterative process and it is likely that the change of one parameter also varies the others. Therefore after each engineering step the new fluxes should be determined. So we believe that the continuous ${ }^{34} \mathrm{~S}$ labeling described in this work may be a valuable tool for systematic strain improvement processes and deeper understanding of large scale production in bioreactors.

\section{Methods}

MATLAB implementation of the model and sensitivity analysis

The implementation of the model was done in MATLAB (additional file 1: MATLAB implementation of the kinetic model), and in its framework it is based on the work by Bibila et al. [22,32]. The model is formulated as set of ordinary differential equations, which are then solved over time using an ODE solver. For our secretion model we used an implicit linear multistep solver (MATLAB ode15s), because it is more appropriate for chemical or biochemical problems than an explicit Runge-Kutta pair solver [33].

To evaluate the behavior of the model concerning the input parameters, namely degradation, secretion and intracellular protein formation, always two of these parameters were varied against each other. The values were then plotted against the extracellular Fab3H6 concentrations in a three dimensional representation. The three dimensional plots were created using the MATLAB functions meshgrid and surf (additional file 2: Sensitivity analysis of the kinetic parameters).

\section{Yeast strain}

The $P$. pastoris strain X-33 used in this study expressed the antibody fragment Fab3H6, previously described by Baumann et al. [27] and Dragosits et al. [34]. Both antibody chains are under the control of the constitutive 
GAP-promoter and are secreted via the Saccharomyes cerevisiae $\alpha$-mating factor secretion signal. Fab3H6 is the anti-idiotypic antibody of the HIV neutralizing antibody 2F5. It has a molecular weight of $47.38 \mathrm{kDa}$ and has 16 sulfur containing amino acids, 11 cysteines and 5 methionines $[35,36]$.

\section{Chemostat cultivation}

A preculture was incubated at $28^{\circ} \mathrm{C}$ for $24 \mathrm{~h}$ and 180 rpm on YPG (per liter: $10 \mathrm{~g}$ yeast extract, $20 \mathrm{~g}$ peptone, $10 \mathrm{~g}$ glycerol). The culture was harvested by centrifugation, resuspended in $50 \mathrm{ml}$ sterile batch medium and used to inoculate $1.0 \mathrm{~L}$ batch medium in the bioreactor (Minifors, Infors, Switzerland) to a starting optical density (OD600) of 1.0.

After a batch phase of approximately 24 hours the continuous culture was started at a dilution rate of $\mathrm{D}=$ $0.1 \mathrm{~h}^{-1}$ with a corresponding feed medium and harvest flow rate of $100 \mathrm{~g} \mathrm{~h}^{-1}$. Cultivation conditions were controlled constantly, the temperature at $25^{\circ} \mathrm{C}, \mathrm{pH}$ at 5.0 with $25 \%$ ammonium hydroxide and $\mathrm{pO}_{2}$ at $20 \%$ by controlling the stirrer speed between 600 and $1200 \mathrm{rpm}$. Air flow was kept constant at 1.5 vvm (volume gas per volume medium and minute).

The batch medium contained per liter: $40 \mathrm{~g}$ glycerol, $2.0 \mathrm{~g}$ citric acid, $12.6 \mathrm{~g}(\mathrm{NH})_{2} \mathrm{HPO}_{4}, 0.5 \mathrm{~g} \mathrm{MgSO}_{4} \cdot 7$ $\mathrm{H}_{2} \mathrm{O}, 0.9 \mathrm{~g} \mathrm{KCl}, 0.022 \mathrm{~g} \mathrm{CaCl}_{2} \cdot 2 \mathrm{H}_{2} \mathrm{O}, 2 \mathrm{ml}$ biotin stock solution $\left(0.2 \mathrm{~g} \mathrm{~L}^{-1}\right)$ and $4.6 \mathrm{ml}$ PTM1 trace salt stock solution. The $\mathrm{pH}$ was set to 5.0 with $25 \% \mathrm{HCl}$. The PTM1 trace salt stock solution contained per liter: $65.0 \mathrm{~g} \mathrm{FeSO}_{4} \cdot 7 \mathrm{H}_{2} \mathrm{O}, 20.0 \mathrm{~g} \mathrm{ZnCl}_{2}, 6.0 \mathrm{~g} \mathrm{CuSO}_{4} \cdot 5$ $\mathrm{H}_{2} \mathrm{O}, 3.36 \mathrm{~g} \mathrm{MnSO}_{4} \cdot 1 \mathrm{H}_{2} \mathrm{O}, 0.82 \mathrm{~g} \mathrm{CoCl}_{2} \cdot 6 \mathrm{H}_{2} \mathrm{O}, 0.2$ $\mathrm{g} \mathrm{Na}_{2} \mathrm{MoO}_{4} \cdot 2 \mathrm{H}_{2} \mathrm{O}, 0.08 \mathrm{~g} \mathrm{NaI}, 0.02 \mathrm{~g} \mathrm{H}_{3} \mathrm{BO}_{3}$ and 5 $\mathrm{ml} \mathrm{H}_{2} \mathrm{SO}_{4}$ (95- 98\%).

In the chemostat medium sodium sulfate was used as the only sulfur source. Per liter this medium contained $1.0 \mathrm{~g}$ citric acid monohydrate, 55 g glucose $-1 \mathrm{H}_{2} \mathrm{O}$, $9.83 \mathrm{~g}\left(\mathrm{NH}_{4}\right)_{2} \mathrm{HPO}_{4}, 0.41 \mathrm{~g} \mathrm{MgCl} \mathrm{Mg}_{2} \cdot 6 \mathrm{H}_{2} \mathrm{O}, 0.29 \mathrm{~g}$ $\mathrm{Na}_{2} \mathrm{SO}_{4}, 1.7 \mathrm{~g} \mathrm{KCl}, 0.01 \mathrm{~g} \mathrm{CaCl}_{2} \cdot 2 \mathrm{H}_{2} \mathrm{O}, 2.0 \mathrm{ml}$ biotin stock solution $\left(0.2 \mathrm{~g} \mathrm{~L}^{-1}\right)$ and $1.6 \mathrm{~g}$ PTM2 trace salt stock solution. The trace salt stock solution PTM2 contained (per liter): $63.3 \mathrm{~g} \mathrm{FeCl}_{2} \cdot 6 \mathrm{H}_{2} \mathrm{O}, 20.0 \mathrm{~g} \mathrm{ZnCl}_{2}$, $5.77 \mathrm{~g} \mathrm{CuCl}_{2} 2 \mathrm{H}_{2} \mathrm{O}, 3.94 \mathrm{~g} \mathrm{MnCl}_{2} \cdot 4 \mathrm{H}_{2} \mathrm{O}, 0.82 \mathrm{~g}$ $\mathrm{CoCl}_{2} \cdot 6 \mathrm{H}_{2} \mathrm{O}, 0.2 \mathrm{~g} \mathrm{Na}_{2} \mathrm{MoO}_{4} \cdot 2 \mathrm{H}_{2} \mathrm{O}, 0.08 \mathrm{~g} \mathrm{NaI}$, $0.02 \mathrm{~g} \mathrm{H}_{3} \mathrm{BO}_{3}$ and $5 \mathrm{ml} \mathrm{HCl} \mathrm{(32 \% ).}$

For the continuous labeling enriched ${ }^{34} \mathrm{~S}$ sodium sulfate (isotopic distribution: $<0.1 \%{ }^{32} \mathrm{~S}, 1.1 \%{ }^{33} \mathrm{~S}, 98.8 \%$ ${ }^{34} \mathrm{~S}$ and $<0.05 \%{ }^{36} \mathrm{~S}$ ) from Isoflex USA was used in the chemostat medium.

\section{${ }^{34}$ S labeling}

Cells were grown for at least 5 resident times in chemostat to ensure steady state conditions. Continuous ${ }^{34} \mathrm{~S}$ labeling was started by changing the feed to the ${ }^{34} \mathrm{~S}$ enriched medium. In addition, at the same time, a labeled sodium sulfate pulse, $5 \mathrm{~mL}$ sterile solution containing in total $600 \mathrm{mg}$ of ${ }^{34} \mathrm{~S}$-labeled sodium sulfate, was administered into the bioreactor. The change in the ${ }^{32} \mathrm{~S}$ to ${ }^{34} \mathrm{~S}$ ratio of the intra- and extracellular Fab3H6 was followed for 8 hours.

\section{Sampling}

Samples were taken to determine the yeast cell dry mass, the extra- and intracellular Fab3H6 concentration and for immunoprecipitation of extra- and intracellular Fab3H6. During the ${ }^{34}$ S labeling samples were taken up to 6 times per hour. In this cases sample volume has to be kept small and therefore no biomass analysis was performed thereof.

The dead volume of the harvest port is $5 \mathrm{~mL}$ and therefore the first $5 \mathrm{~mL}$ culture broth were withdrawn. $10 \mathrm{~mL}$ culture broth were used for yeast dry mass (YDM) determination. For intracellular Fab3H6 measurements four cell pellets of $2 \mathrm{~mL}$ culture $(0.05 \mathrm{~g}$ YDM each in capped screw tube, Biozym) were collected (1 min centrifugation at $4^{\circ} \mathrm{C}$ and $13.000 \mathrm{rpm}$, followed by quick freezing in liquid nitrogen). The supernatant was used for all extracellular measurements.

To enable the necessary sampling volume of at least $13 \mathrm{~mL}$, the continuous harvest was replaced by discontinuous sampling. The sample volumes taken out from the bioreactor were exactly the volumes that should have been harvested by the pump. This caused a slight variation of the preset dilution rate of $0.1 \mathrm{~h}^{-1}$. However, the calculated dilution rates are in the range of minimum $0.0998 \mathrm{~h}^{-1}$ and maximum $0.1013 \mathrm{~h}^{-1}$ (calculation not shown) and it can be assumed that these changes have no significant influence.

\section{Mechanical cell lysis of $P$. pastoris}

The cell pellets, containing $0.05 \mathrm{~g}$ YDM in capped screwing tubes, were washed with $0.5 \mathrm{~mL}$ PBS (per liter: $8.0 \mathrm{~g} \mathrm{NaCl}, 0.2 \mathrm{~g} \mathrm{KCl}, 1.8 \mathrm{~g} \mathrm{Na}_{2} \mathrm{HPO}_{4} \cdot 2 \mathrm{H}_{2} \mathrm{O}, 0.24 \mathrm{~g}$ $\left.\mathrm{KH}_{2} \mathrm{PO}_{4}\right)$ and further resuspended in $0.5 \mathrm{~mL}$ lysis buffer. $0.5 \mathrm{~mL}$ of glass beads (acid washed, 0.4-0.6 mm, Satorius) were added. Cells were mechanically disrupted by using the FastPrep system (MP Biomedicals; settings: 3 times $20 \mathrm{~s}$ shaking at $\left.6.5 \mathrm{~m} \mathrm{~s}^{-1}\right)$. At the bottom of the tubes small holes were pierced with a hot needle and the tubes were put onto a $2 \mathrm{~mL}$ eppendorf tube. Cell lysates were collected by moderate centrifugation ( $1 \mathrm{~min}$ with $1.000 \mathrm{~g}$ ). Cells debris and glass beads were washed with $0.5 \mathrm{~mL}$ lysis buffer followed by the same moderate centrifugation step. Lysates were cleared by centrifugation (15 $\mathrm{min}$ at $13.000 \mathrm{~g}$ ) and the supernatants were taken for further analysis (Fab immunoprecipitation or quantification). During the whole procedure samples were kept at maximum $4^{\circ} \mathrm{C}$. 
Lysis buffer: $1 \%(\mathrm{w} / \mathrm{v})$ triton X-100, $50 \mathrm{mM}$ Tris. $\mathrm{HCl}$ $\mathrm{pH}=7.4,300 \mathrm{mM} \mathrm{NaCl}, 5 \mathrm{mM}$ EDTA and $0.02 \%(\mathrm{w} / \mathrm{v})$ sodium azide. Immediately before use inhibitors were added: 1 tablet of protease inhibitor (Sigma, S8820) per $20 \mathrm{~mL}$ buffer, proteasome inhibitor MG-132 to a final concentration of $5 \mu \mathrm{M}$ and lysosomal inhibitor chloroquine to a final concentration of $50 \mu \mathrm{M}$.

\section{Fab3H6 immunoprecipitation}

The procedure was adapted from the Current Protocols in Molecular Biology, chapter 10.16 "Immunoprecipitation" [37]. $80 \mu \mathrm{L}$ of the anti-human IgG agarose suspension (Sigma-Aldrich) were added to $1 \mathrm{~mL}$ cleared cell lysate or $1 \mathrm{~mL}$ of culture supernatant and incubated for 2 hours at $4^{\circ} \mathrm{C}$ in a tube rotator. The agarose slurry was transferred onto PVDF membranes (Ultrafree ${ }^{\circledR}$-MC Centrifugal Filter Units, $0.45 \mu \mathrm{m}$, Millipore) and washed four times with $0.5 \mathrm{~mL}$ ice-cold washing buffer and twice with $0.5 \mathrm{~mL}$ ice-cold PBS (centrifuged each time 5 sec at $3.000 \mathrm{~g}$ ). To disaggregate the proteins from the matrix, the agarose suspension was incubated two times for 10 minutes with $120 \mu \mathrm{L}$ elution buffer at room temperature. The eluates were collected by centrifugation ( 5 sec at $3.000 \mathrm{~g}$ ). The buffer was changed to PBS and the solution was concentrated by the factor 10 by using the $10 \mathrm{kDa}$ Amicon ${ }^{\circledR}$ Ultra-0.5 centrifugal filter devices (Millipore). The immunopurified Fab3H6 solutions were used for sulfur isotope determination (see below).

Wash buffer: $0.1 \%(\mathrm{w} / \mathrm{v})$ triton X-100, $50 \mathrm{mM}$ Tris. $\mathrm{HCl} \mathrm{pH}=7.4,300 \mathrm{mM} \mathrm{NaCl}, 5 \mathrm{mM}$ EDTA and $0.02 \%(\mathrm{w} / \mathrm{v})$ sodium azide. Immediately before use $0.1 \%$ sodium deoxycholate was added.

Elution buffer: $6 \mathrm{M}$ guanidine hydrochloride, $100 \mathrm{mM}$ Tris $\cdot \mathrm{HCl} \mathrm{pH}=8.5,5 \mathrm{mM}$ EDTA and $0.02 \%(\mathrm{w} / \mathrm{v})$ sodium azide.

\section{Sulfur isotope ratio determination}

An inert titanium HPLC gradient system (Rheos 2000, Flux Instruments AG, Basel, Switzerland) with a metal-free autosampler (HTC PAL Autosampler, Thermo Fisher Scientific Inc., Waltham, USA) was used in combination with a high resolution inductively coupled plasma sector field mass spectrometer, ICP-SFMS (Element 2, Thermo Scientific Inc., Bremen, Germany). Sample introduction system consisted of a nebulizer (PFA-ST, Elemental Scientific Inc., Omaha, Nebrasca, USA) and a cooled $\left(5^{\circ} \mathrm{C}\right)$ cyclonic silica glass spray chamber (PC3, ISA Elemental Scientific). Measured isotopes were ${ }^{34} \mathrm{~S}$ and ${ }^{32} \mathrm{~S}$. Mass resolution was set to 4000. ${ }^{32} \mathrm{~S}$ was used as lock mass during measurement for instrumental mass drift correction. Dwell time per isotope was $0.1 \mathrm{sec}$. For separation by size exclusion chromatography a KW402.51E column (Shodex, Showa Denko K. K., Kawasaki, Japan) was used. Column dimensions were $1 \times$ $150 \mathrm{~mm}$. Separation was carried out under native conditions, with a $50 \mathrm{mM}$ ammonium acetate, $\mathrm{pH} 6$ eluent. The SEC flow was $50 \mu \mathrm{L} \mathrm{min}^{-1}$; injection volume was set to $2 \mu \mathrm{L}$. The integration of all chromatographic data from SEC-ICP-SFMS analysis was carried out using Chromeleon software (Version 6.7, Dionex, Sunnyvale, California, USA). Fab monomer and heterodimer dimer coeluted from the SEC column under the selected conditions. The ${ }^{34} \mathrm{~S} /{ }^{32} \mathrm{~S}$ ratio in the Fab samples was determined with a long term repeatability of $5 \%$ ( 12 hours, $\mathrm{N}=5$ ).

\section{Sulfur isotope determination of the inorganic compounds} in the supernatant

The supernatant of the culture broth has been separated from all molecules with a size larger than $3 \mathrm{kDa}$ by ultrafiltration (3 kDa Amicon ${ }^{\circledR}$, Millipore). The sulfur in the remaining solution, mainly from inorganic sulfate, was analyzed by ICP-SFMS for its sulfur ratio (see above).

\section{Biomass determination by dry cell mass}

Two times $5 \mathrm{~mL}$ culture broth were centrifuged. The pellets were resuspended in $10 \mathrm{~mL} \mathrm{RO}-\mathrm{H}_{2} \mathrm{O}$ (reverse osmosis water) and recentrifuged. The washed pellets were again resuspended in $\mathrm{RO}-\mathrm{H}_{2} \mathrm{O}$, transferred to weighed beakers and dried at $105^{\circ} \mathrm{C}$ until constant weight.

\section{SDS-PAGE and silver staining}

$10 \mu \mathrm{L}$ of the IP concentrate were run on a non-reducing sodium dodecyl sulfate (SDS) 4 to $12 \%$ polyacrylamide gel (Invitrogen) with MOPS buffer (morpholinepropanesulfonic acid) at $200 \mathrm{~V}$ for one hour and silver stained according to the protocol in the Current Protocols in Molecular Biology, chapter 10.6 [38].

\section{Fab3H6 quantification}

Quantification was done by sandwich ELISA as described in a previous study [27].

\section{Additional material}

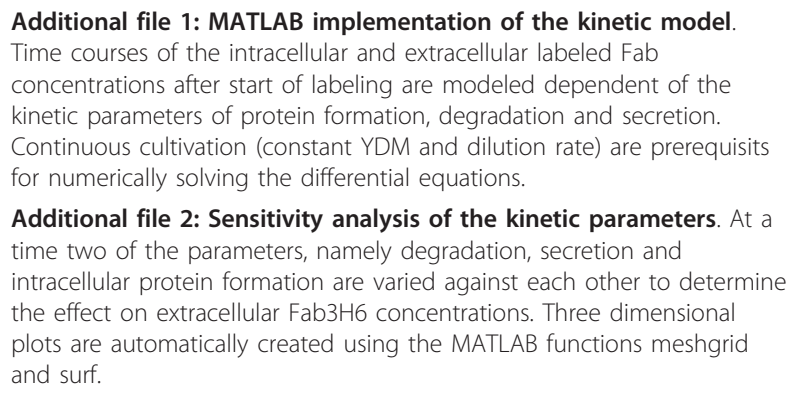

Additional file 2: Sensitivity analysis of the kinetic parameters. At a time two of the parameters, namely degradation, secretion and intracellular protein formation are varied against each other to determine the effect on extracellular Fab3H6 concentrations. Three dimensional plots are automatically created using the MATLAB functions meshgrid and surf.

\section{Abbreviations}

$\mathrm{K}_{\text {Deg: }}$ : time constant for intracellular protein degradation; $\mathrm{K}_{\text {Dil }}$ : time constant for protein dilution; $K_{\text {Har: }}$ time constant for protein harvest; $K_{\text {Sec }}$ : time 
constant for protein secretion; $\mathrm{P}_{\mathrm{e}}$ : extracellular protein concentration; $\mathrm{P}_{\mathrm{i}}$ : intracellular protein concentration; $\mathrm{P}^{32} \mathrm{~S}$ : concentration of the ${ }^{32} \mathrm{~S}$ isotope containing protein; $\mathrm{q}_{\mathrm{Deg}}$ : intracellular protein degradation rate; $\mathrm{q}_{\mathrm{Dil}}$ : protein dilution rate; $q_{\text {Har: }}$ protein harvest rate; $q_{p i}$ intracellular protein formation

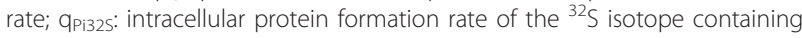
protein; $q_{s e c}$ : protein secretion rate; $t_{1 / 2}$ Deg: half time of intracellular protein degradation; $\mathrm{t}_{1 / 2}$ Dil: half time of protein dilution; $\mathrm{t}_{1 / 2}$ sec: half time of protein secretion.

\section{Acknowledgements}

We want to thank Katrin Benakovitsch for support in method development, especially with respect to immunoprecipitation, and Marizela Delic and Markus Buchetics for fruitful discussions. This project was financially supported by Boehringer Ingelheim RCV (Vienna, Austria). ABG was supported by the project "Competence team Molecular Biology" by the City of Vienna, MA27.

\section{Author details}

${ }^{1}$ University of Natural Resources and Life Sciences, Department of Biotechnology, Muthgasse 18, 1190 Vienna, Austria. ${ }^{2}$ University of Applied Sciences FH-Campus Vienna, School of Bioengineering, Muthgasse 18, 1190 Vienna, Austria. ${ }^{3}$ University of Natural Resources and Life Sciences, Department of Chemistry, Muthgasse 18, 1190 Vienna, Austria. ${ }^{4}$ Austrian Centre of Industrial Biotechnology (ACIB GmbH), Muthgasse 11, 1190 Vienna, Austria.

\section{Authors' contributions}

MP performed most of the experimental work, formulated and solved the kinetic model, and drafted the manuscript. MM contributed to study design, data analysis and interpretation. GK and SH designed and performed ICP-MS analysis of sulfur isotopes. ABG implemented the kinetic model in MATLAB and set up a MATLAB script for sensitivity analysis. DM conceived of the study and contributed to data analysis, interpretation and manuscript writing. All authors read and approved the final manuscript.

\section{Competing interests}

The authors declare that they have no competing interests.

Received: 16 May 2011 Accepted: 26 June 2011 Published: 26 June 2011

\section{References}

1. Porro D, Gasser B, Fossati T, Maurer M, Branduardi P, Sauer M, Mattanovich D: Production of recombinant proteins and metabolites in yeasts: when are these systems better than bacterial production systems? Appl Microbiol Biotechnol 2011, 89(4):939-948.

2. Idiris A, Tohda $H$, Kumagai $H$, Takegawa K: Engineering of protein secretion in yeast: strategies and impact on protein production. Appl Microbiol Biotechnol 2010, 86(2):403-417

3. Lopes TS, Hakkaart GJ, Koerts BL, Raué HA, Planta RJ: Mechanism of highcopy-number integration of pMIRY-type vectors into the ribosomal DNA of Saccharomyces cerevisiae. Gene 1991, 105(1):83-90.

4. Marx H, Mecklenbräuker A, Gasser B, Sauer M, Mattanovich D: Directed gene copy number amplification in Pichia pastoris by vector integration into the ribosomal DNA locus. FEMS Yeast Res 2009, 9(8):1260-1270.

5. Hartner FS, Ruth C, Langenegger D, Johnson SN, Hyka P, Lin-Cereghino GP, Lin-Cereghino J, Kovar K, Cregg JM, Glieder A: Promoter library designed for fine-tuned gene expression in Pichia pastoris. Nucleic Acids Res 2008, 36(12):e76.

6. Gasser B, Maurer M, Rautio J, Sauer M, Bhattacharyya A, Saloheimo M, Penttilä M, Mattanovich D: Monitoring of transcriptional regulation in Pichia pastoris under protein production conditions. BMC Genomics 2007, 8:179.

7. Hohenblum H, Gasser B, Maurer M, Borth N, Mattanovich D: Effects of gene dosage, promoters, and substrates on unfolded protein stress of recombinant Pichia pastoris. Biotechnol Bioeng 2004, 85(4):367-375.

8. Kauffman KJ, Pridgen EM, Doyle FJ, Dhurjati PS, Robinson AS: Decreased protein expression and intermittent recoveries in BiP levels result from cellular stress during heterologous protein expression in Saccharomyces cerevisiae. Biotechnol Prog 2002, 18(5):942-950.
9. Ng DT, Spear ED, Walter P: The unfolded protein response regulates multiple aspects of secretory and membrane protein biogenesis and endoplasmic reticulum quality control. J Cell Biol 2000, 150(1):77-88.

10. Travers KJ, Patil CK, Wodicka L, Lockhart DJ, Weissman JS, Walter P: Functional and genomic analyses reveal an essential coordination between the unfolded protein response and ER-associated degradation. Cell 2000, 101(3):249-258.

11. Harding HP, Zhang $Y$, Ron D: Protein translation and folding are coupled by an endoplasmic-reticulum-resident kinase. Nature 1999, 397(6716):271-274

12. Schröder M, Kaufman RJ: ER stress and the unfolded protein response. Mutat Res 2005, 569(1-2):29-63.

13. Hirsch C, Gauss R, Horn S, Neuber O, Sommer T: The ubiquitylation machinery of the endoplasmic reticulum. Nature 2009, 458(7237):453-460.

14. Zhang $W$, Zhao HL, Xue C, Xiong XH, Yao XQ, Li XY, Chen HP, Liu ZM: Enhanced secretion of heterologous proteins in Pichia pastoris following overexpression of Saccharomyces cerevisiae chaperone proteins. Biotechnol Prog 2006, 22(4):1090-1095.

15. Damasceno LM, Anderson KA, Ritter G, Cregg JM, Old LJ, Batt CA: Cooverexpression of chaperones for enhanced secretion of a singlechain antibody fragment in Pichia pastoris. Appl Microbiol Biotechnol 2007, 74(2):381-389.

16. Klabunde J, Kleebank S, Piontek M, Hollenberg CP, Hellwig S, Degelmann A: Increase of calnexin gene dosage boosts the secretion of heterologous proteins by Hansenula polymorpha. FEMS Yeast Res 2007, 7(7):1168-1180

17. Ruohonen L, Toikkanen J, Tieaho V, Outola M, Soderlund H, Keranen S: Enhancement of protein secretion in Saccharomyces cerevisiae by overproduction of Sso protein, a late-acting component of the secretory machinery. Yeast 1997, 13(4):337-351.

18. Gasser B, Sauer M, Maurer M, Stadlmayr G, Mattanovich D: Transcriptomicsbased identification of novel factors enhancing heterologous protein secretion in yeasts. App/ Environ Microbiol 2007, 73(20):6499-6507.

19. Noe D, Delenick J: Quantitative analysis of membrane and secretory protein processing and intracellular transport. J Cell Sci 1989, 92(Pt 3):449-459.

20. Batt BC, Kompala DS: A structured kinetic modeling framework for the dynamics of hybridoma growth and monoclonal antibody production in continuous suspension cultures. Biotechnol Bioeng 1989, 34(4):515-531.

21. Hirschberg K, Lippincott-Schwartz J: Secretory pathway kinetics and in vivo analysis of protein traffic from the Golgi complex to the cell surface. FASEB J 1999, 13(Suppl 2):S251-256.

22. Bibila T, Flickinger M: A model of interorganelle monoclonal antibody transport and secretion in mouse hybridoma cells. Biotechnol Bioeng 1991, 38(7):767-780.

23. Whiteley E, Hsu T, Betenbaugh M: Modeling assembly, aggregation, and chaperoning of immunoglobulin $\mathrm{G}$ production in insect cells. Biotechnol Bioeng 1997, 56(1):106-116.

24. Gonzalez R, Andrews BA, Asenjo JA: Metabolic control analysis of monoclonal antibody synthesis. Biotechnol Prog 2001, 17(2):217-226.

25. Ho Y, Varley J, Mantalaris A: Development and analysis of a mathematical model for antibody-producing GS-NSO cells under normal and hyperosmotic culture conditions. Biotechnol Prog 2006, 22(6):1560-1569.

26. Belle A, Tanay A, Bitincka L, Shamir R, O'Shea EK: Quantification of protein half-lives in the budding yeast proteome. Proc Natl Acad Sci USA 2006, 103(35):13004-13009.

27. Baumann K, Maurer M, Dragosits M, Cos O, Ferrer P, Mattanovich D: Hypoxic fed-batch cultivation of Pichia pastoris increases specific and volumetric productivity of recombinant proteins. Biotechnol Bioeng 2008 100(1):177-183.

28. Maurer M, Kühleitner M, Gasser B, Mattanovich D: Versatile modeling and optimization of fed batch processes for the production of secreted heterologous proteins with Pichia pastoris. Microb Cell Fact 2006, 5:37.

29. Losev E, Reinke C, Jellen J, Strongin D, Bevis B, Glick B: Golgi maturation visualized in living yeast. Nature 2006, 441(7096):1002-1006.

30. Yee JC, Jacob NM, Jayapal KP, Kok YJ, Philp R, Griffin TJ, Hu WS: Global assessment of protein turnover in recombinant antibody producing myeloma cells. J Biotechnol 2010, 148(4):182-193.

31. Pignède G, Wang HJ, Fudalej F, Seman M, Gaillardin C, Nicaud JM: Autocloning and amplification of LIP2 in Yarrowia lipolytica. App/ Environ Microbiol 2000, 66(8):3283-3289. 
32. Bibila TA, Flickinger MC: Use of a structured kinetic model of antibody synthesis and secretion for optimization of antibody production systems: I. Steady-state analysis. Biotechnol Bioeng 1992, 39(3):251-261.

33. Shampine LF, Reichelt MW, Kierzenka JA: Solving index-I DAEs in MATLAB and Simulink. Siam Review 1999, 41(3):538-552.

34. Dragosits M, Stadlmann J, Albiol J, Baumann K, Maurer M, Gasser B, Sauer M, Altmann F, Ferrer P, Mattanovich D: The effect of temperature on the proteome of recombinant Pichia pastoris. J Proteome Res 2009, 8(3):1380-1392.

35. Gach J, Quendler H, Strobach S, Katinger H, Kunert R: Structural analysis and in vivo administration of an anti-idiotypic antibody against $\mathrm{mAb}$ 2F5. Mol Immunol 2008, 45(4):1027-1034.

36. Kunert R, Weik R, Siegler G, Katinger H: Anti-idiotypic antibody inducing hiv-1 neutralizing antibodies. US Patent 2005, 2005080240.

37. Bonifacino J, Dell'Angelica E, Springer T: Immunoprecipitation. Curr Protoc Mol Biol 2001, 10(10):16.

38. Sasse J, Gallagher SR: Staining proteins in gels. Curr Protoc Mol Biol 2009, 10(10):16.

doi:10.1186/1475-2859-10-47

Cite this article as: Pfeffer et al:: Modeling and measuring intracellular fluxes of secreted recombinant protein in Pichia pastoris with a novel ${ }^{34}$ S labeling procedure. Microbial Cell Factories 2011 10:47.

\section{Submit your next manuscript to BioMed Central} and take full advantage of:

- Convenient online submission

- Thorough peer review

- No space constraints or color figure charges

- Immediate publication on acceptance

- Inclusion in PubMed, CAS, Scopus and Google Scholar

- Research which is freely available for redistribution

Submit your manuscript at www.biomedcentral.com/submit 